\title{
Effect of Health Counseling about IUD to Knowledge and Attitude on Married Couple in Serang Regency
}

\author{
Suraya Mansur, ${ }^{1}$ Dewi Hartaningrum, ${ }^{1}$ Titi Legiati $^{2}$ \\ ${ }^{1}$ Department of Communication Science, \\ Faculty of Communication Science, Universitas Mercu Buana, Jakarta, Indonesia, \\ ${ }^{2}$ Department of Midwifery, Politeknik Kesehatan Kementerian Kesehatan Bandung, Bandung, Indonesia
}

\begin{abstract}
Health counseling about contraception is essential to provide more knowledge about how to use contraception and improve the attitude and behavior of the family toward the Family Planning Program. This study aimed to determine the effect of counseling on the intrauterine device (IUD) knowledge and attitudes. This research was conducted in Bojong Menteng village, Tunjung Teja district, Serang regency, in February-July 2019. This study used the true experimental design method to look for the treatment effect on others in controlled conditions using pretest-posttest control group design and a quantitative research approach. In this study, the experimental and the control group are given a pretest to find out the initial conditions to see whether there are differences between the experimental group and the control group. Samples used random sampling techniques where 40 people were divided into two groups who have not used the IUD and have two children and more. The study employed paired $t$ test and unpaired t test to analyze the data. The results showed that the average knowledge of the experiment group increased to 72, and the average knowledge of the control group increased to 70.2. In addition, the average attitude of the experiment group increased to 82.35. The difference between the two groups was only seen in wearing, where the experimental group showed positive behavior towards using the IUD. The conclusion is that counseling through leaflets, information education counseling kit, and direct explanation have positive responses.
\end{abstract}

Keywords: Attitudes, counseling, health communication, IUD, knowledge

\section{Efek Penyuluhan Kesehatan mengenai IUD terhadap Pengetahuan dan Sikap pada Pasangan di Kabupaten Serang}

\begin{abstract}
Abstrak
Penyuluhan kesehatan tentang kontrasepsi penting dilakukan untuk memberikan lebih banyak pengetahuan tentang cara penggunaan kontrasepsi serta meningkatkan sikap dan perilaku keluarga terhadap Program Keluarga Berencana. Penelitian ini bertujuan mengetahui pengaruh penyuluhan tentang alat kontrasepsi dalam rahim (AKDR) terhadap pengetahuan dan sikap. Penelitian ini dilaksanakan di Desa Bojong Menteng, Kecamatan Tunjung Teja, Kabupaten Serang pada Februari-Juli 2019. Metode yang digunakan true experimental design dengan menggunakan pretestposttest control group design dan pendekatan kuantitatif untuk mencari pengaruh perlakuan terhadap yang lain dalam kondisi yang terkendalikan. Dalam penelitian ini kelompok eksperimen dan kelompok kontrol diberi pretest untuk mengetahui keadaan awal adakah perbedaan antara kelompok eksperimen dan kelompok kontrol. Sampel menggunakan teknik random sampling berjumlah 40 orang dibagi dalam dua kelompok yang belum menggunakan AKDR dan mempunyai dua anak dan lebih. Data dianalisis dengan uji t berpasangan dan uji t tidak berpasangan. Hasil penelitian menunjukkan bahwa rerata pengetahuan kelompok eksperimen meningkat menjadi 72, sedangkan rerata pengetahuan kelompok kontrol meningkat menjadi 70,2. Selain itu, rerata sikap kelompok eksperimen meningkat menjadi 82,35. Perbedaan kedua kelompok tersebut hanya terlihat pada perilaku memakai saja bahwa kelompok eksperimen menunjukkan perilaku positif terhadap pemakaian AKDR. Hal tersebut menunjukkan bahwa penyuluhan melalui leaflet, kit konseling pendidikan informasi, dan penjelasan langsung memiliki respons positif.
\end{abstract}

Kata kunci: AKDR, komunikasi kesehatan, pengetahuan, penyuluhan, sikap 


\section{Introduction}

Health communication is one of the essential efforts in limiting the number of populations. Family planning programs and reproductive health become the main issues to be discussed in health communication as they significantly impact family quality. The decision to use contraception should have overcome the population issue. The local government has authority and flexibility in problem formulation and policymaking to reduce the number of populations. On the other hand, society needs to receive accurate information and understanding of contraception. Information on contraception is prominent in measuring the success of the family planning program. ${ }^{1}$ The policy to support Family Planning Program should be improved, especially the communication skill of the counselor in providing Family Planning counseling. ${ }^{2}$

Many fertile married couples do not understand the benefit of IUD with the longacting contraception method (LACM) and how contraception has fewer side effects than other contraceptions do. Around 96\% of Indonesian women only know pill and injected contraceptives, also known as non-LACMs, while only $73.8 \%$ know about the intrauterine device (IUD) as contraception. ${ }^{+}$

Human behavior could change if there is a stimulus. The stimulus could be in the form of counseling or information related to the behavior. For example, if someone who does not use contraception could change her mind to use contraception because of the counseling or other program. This study aims to analyze the effect of health counseling about intrauterine device (IUD) on the knowledge and attitude of the fertile married couple.

\section{Methods}

The researcher in this study created leaflets independently and conducted two groups experiment study on the effect of counseling by leaflet or leaflet followed by an explanation. Thus, according to the elaboration above, the research question of this study is how does health counseling about IUD affect the knowledge and attitude of fertile married couples in Bojong Menteng village, Tunjung Teja district, Serang regency?

This study used the S-O-R theory, which considers attitude change as similar to the learning process. In examining attitude, three essential variables support the learning process, attention, understanding, and acceptance. The message in this theory became the stimulus. The organism is individual or communicant. Furthermore, a response is reaction, perception, affect, or consequence; thus, this theory's response element is the effect. ${ }^{3-6}$ The change in attitude happened when the communicant has the willingness to use IUD based on the counseling that has been given.

As Rogers ${ }^{7}$ stated, this study is also related to health communication: "health communication has been defined as referring to any human communication whose content is concerned with health." A study on communication health was conducted by Thomas, ${ }^{8}$ Rice and Atkin ${ }^{9}$ on public health, Abroms and Lefebvre ${ }^{10}$ on health campaign by Obama, health campaign, ${ }^{11}$ and health campaign through social marketing. ${ }^{12}$

This study used the true experiment design method. The method is employed to determine the effect of specific treatment toward others in a controlled condition, where this study is a quantitative research method. ${ }^{13}$ In addition, this study used a pretest-posttest control group design. Two groups in this design are selected randomly and given a pretest to determine the initial condition whether there is a difference between the experiment group and the control group. $^{13}$

The variables of this study are independent variables and dependent variables. Independent variables are counseling by leaflet and information education counseling/komunikasi, informasi, dan edukasi (KIE) kit, while dependent variables are knowledge and attitude of fertile married couples toward IUD. The population is 562 fertile married couples in Bojong Menteng village, Tunjung Teja district, Serang regency.

This study used simple random sampling in collecting the sample by choosing 40 respondents randomly from 562 fertile married couples that are registered as Family Planning participants and have not used IUD in Bojong Menteng village, Tunjung Teja district, Serang regency with the criteria as follows: fertile married couple that with two or more children, fertile married couples that have not used IUD, fertile married couples who can read and write, and willing to be involved.

The respondents joined the counseling, and the media used is a leaflet and KIE kit. The information given is the definition of IUD, its 
procedure, side effects, benefit, contraindication, induction time, and essential things to be considered after the induction.

The researcher collected primary data through attitude and knowledge questionnaires. The data were taken twice on the same group, which is pretest and posttest data. The steps of collecting data are: Step 1: (1) the researcher explained the aim and procedure of the research to the respondents, then asked for their agreement and

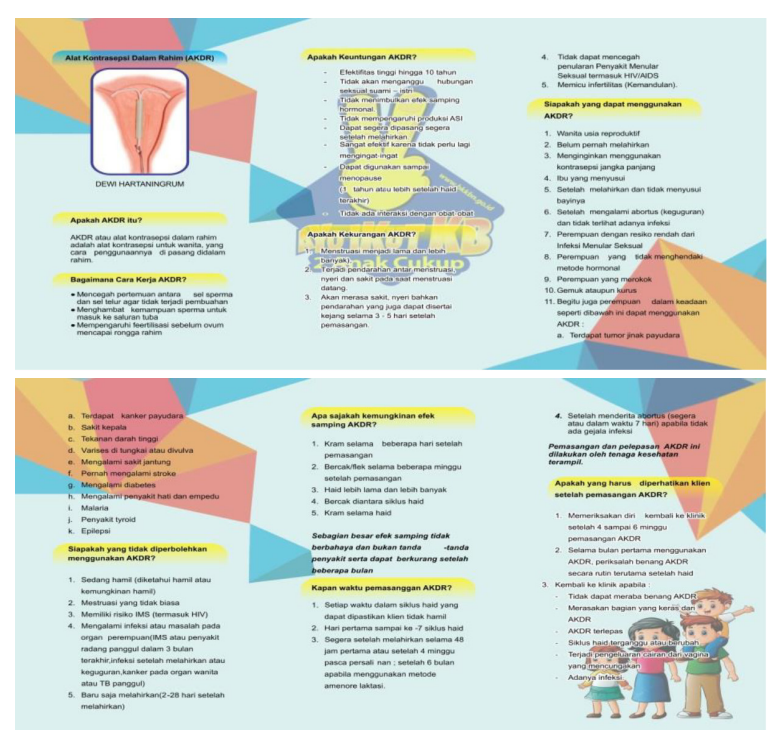

Figure 1 IUD Leaflet

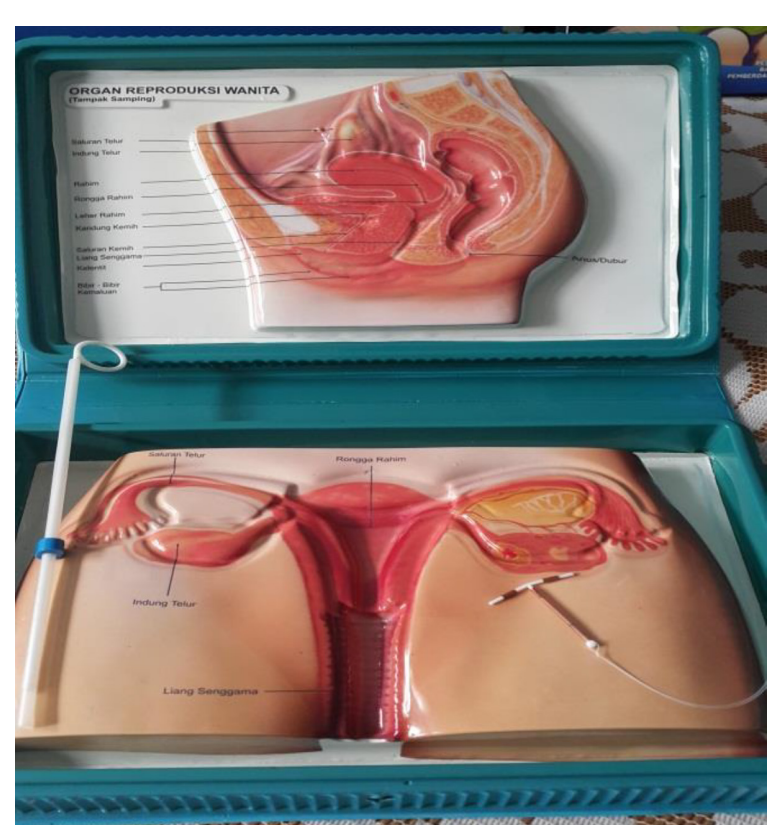

Figure 2 KIE Kit signature on the informed consent provided; (2) the researcher divided respondents into two groups with 20 individuals each; (3) the respondents filled attitude and knowledge on the IUD questionnaire before the treatment was applied; (4) after filling the questionnaire (pretest), the treatment/experiment group (Group 1) joined counseling with leaflet, KIE kit, and explanation for an hour; (5) meanwhile, the control group (Group 2) was given a leaflet without explanation after filling the questionnaire (pretest); (6) all respondents went home and are reminded to be back a week later.

Step II: similar to Step I. Step III: after two counseling sessions, respondents filled the attitude and knowledge of the IUD questionnaire (posttest). Step IV: after the pretest, treatment, and posttest, the researcher observed the respondents' attitudes toward IUD for months to determine whether the respondents are willing to use IUD or not.

This study used a t test sample related/paired in analyzing the data to determine the changes in respondents' knowledge, attitude, and behavior.

The validity test result from the questionnaire is the coefficient of $0.05, \mathrm{r}$ table of 0.361 , total correlation $>0.361$, and positive, then the statement is valid. However, if the statement is not valid, it would be terminated.

A variable is reliable when the Cronbach's alpha value is $>0.60$. In this study, Cronbach's alpha value for the knowledge variable is 0.924 , and the attitude variable is 0.724 , respectively.

\section{Results}

Most of the respondents are elementary and high school graduates. Eight respondents are elementary school graduates (40\%) in the control group, and eight are high school graduates (40\%). Meanwhile, seven respondents are elementary school graduates (35\%) in the intervention group, and seven others are high school graduates (35\%). Most of the respondents have 1-2 children (13 respondents (65\%) in the experiment group and 12 respondents (60\%) in the control group). Most of the respondents used contraceptive injection as 12 respondents (60\%) of the experiment group and ten respondents (50\%) of the control group used contraceptive injection. Most of the respondents are not working, as 18 respondents (90\%) of the experiment group and 20 respondents (100\%) of the control group are unemployed. Husbands of the respondents of both groups are primarily 
Table 1 Paired T Test the Effect of Health Counseling about IUD through Leaflet and KIE Kit on the Knowledge of Experiment Group

\begin{tabular}{lccccc}
\hline Variables & $\mathbf{n}$ & Average \pm & Average Difference $\neq$ & $\mathbf{9 5 \%}$ CI & $\mathbf{p}$ \\
\hline Knowledge & & & & & \\
$\quad$ Pre-treatment & 20 & $65.80 \pm 9.49$ & $6.20 \pm 11.34$ & $0.88-11.51$ & 0.024 \\
$\quad$ Post-treatment & 20 & $72.00 \pm 12.31$ & & & \\
Attitude & & & & & \\
$\quad$ Pre-treatment & 20 & $76.65 \pm 6.99$ & $5.70 \pm 10.72$ & $0.68-10.71$ & 0.028 \\
$\quad$ Post-treatment & 20 & $82.35 \pm 11.83$ & & & \\
\hline
\end{tabular}

Table 2 Paired T Test the Effect of Health Counseling about IUD through Leaflet on the Knowledge of Control Group

\begin{tabular}{lccccc}
\hline Variables & $\mathbf{n}$ & Average \pm & Average Difference $\neq$ & $\mathbf{9 5 \%}$ CI & $\mathbf{p}$ \\
\hline Knowledge & & & & & \\
$\quad$ Pre-treatment & 20 & $60.60 \pm 8.63$ & $9.60 \pm 9.57$ & $5.12-14.08$ & 0.000 \\
$\quad$ Post-treatment & 20 & $82.35 \pm 11.83$ & & & \\
Attitude & & & & & \\
$\quad$ Pre-treatment & 20 & $74.07 \pm 9.59$ & $5.41 \pm 10.70$ & $0.40-10.42$ & 0.036 \\
$\quad$ Post-treatment & 20 & $79.48 \pm 10.57$ & & & \\
\hline
\end{tabular}

working (90\% of the experiment group and $100 \%$ of the control group).

Table 1 shows the $\mathrm{p}$ value of the statistic test was 0.024 , which means alpha $5 \%$, and there was a significant difference in the average knowledge of the experiment group during the intervention. On the other hand, the $\mathrm{p}$ value of the statistic test is 0.028 , which means alpha $5 \%$, and there is a significant difference in the average attitude of the experiment group during the intervention.

The average knowledge of the experiment group before the counseling and intervention was 65.8 , but the number increased to 72 after counseling and intervention using leaflet, explanation, and KIE kit. On the other hand, the average knowledge of the control group before the counseling was 60.6, and the number also increased to 70.2 after counseling using a leaflet.

Table 2 shows the $\mathrm{p}$ value of the statistic test was 0.000 , which means that there was a significant difference in the average knowledge of the control group during the counseling. On the other hand, the $p$ value of the statistic test was 0.036 , which means that there was a significant difference in the average attitude of the control group during the counseling.

The average attitude of the experiment group before the counseling and intervention was 76.65 , but the number increased to 82.35 after counseling and intervention using leaflet,

Table 3 Unpaired T Test the Counseling Effectiveness on the Knowledge on IUD

\begin{tabular}{lcccc}
\hline Variables & $\mathbf{n}$ & Average \pm & $\begin{array}{c}\text { Average Difference } \\
\mathbf{9 5 \%} \text { CI }\end{array}$ & p \\
\hline Knowledge & & & & \\
$\quad$ Experiment group & 20 & $6.20 \pm 11.34$ & $3.40(3.32-10.12)$ & 0.033 \\
$\quad$ Control group & 20 & $9.60 \pm 9.57$ & & \\
Attitude & & & & \\
$\quad$ Experiment group & 20 & $5.45 \pm 10.73$ & $0.05(0.92-6.82)$ & 0.835 \\
$\quad$ Control group & 20 & $5.40 \pm 10.75$ & & \\
\hline
\end{tabular}


Table 4 Respondents' Behavior on IUD Usage

\begin{tabular}{lccc}
\hline \multirow{3}{*}{ Treatment } & \multicolumn{2}{c}{ IUD Usage } & \\
\cline { 2 - 3 } & Not Use & Use & $\mathbf{p}$ \\
\cline { 2 - 3 } & $\mathbf{n}=\mathbf{3 6}$ & $\mathbf{n = 4}$ & \\
\hline Control & 20 & 0 & 0.035 \\
Experiment & 16 & 4 & \\
\hline
\end{tabular}

explanation, and KIE kit. Meanwhile, the average attitude of the control group before counseling was 74.1, and the number also increased to 79.35 after counseling using leaflets.

Table 3 shows no significant differences between the average knowledge of the experiment and the control group $(\mathrm{p}=0.33)$. However, the average knowledge of the control group (9.60) was higher than the average knowledge of the intervention group (6.20). As well, no significant differences between the average attitude of the experiment and the control group ( $\mathrm{p}=0.835)$. However, the average attitude of the experiment group (5.45) was higher than the average knowledge of the control group (5.40).

Thus, despite the difference, both groups showed improvement in knowledge and attitude. An observation was conducted to determine the respondents' behavior toward IUD.

Table 4 showed that there was an effect of counseling on the usage of IUD. The counseling using leaflet, explanation, and KIE kit has led 4 of 20 people in the experiment group to use IUD. Meanwhile, none of the control group respondents used IUD after counseling, only using a leaflet. The data implied that using the KIE kit effectively changed the respondents' behavior as they became more enthusiastic compared to other methods.

\section{Discussion}

A study about knowledge on IUD was conducted by Destyowati, ${ }^{14}$ the increase of IUD usage in the US, ${ }^{15}$ population control strategy using IUD. ${ }^{16}$

Thelong-acting contraception method (LACM) is effective contraception because its failure rate is only $0.58-0.78 \%$. IUD is immediately effective after being inducted, and it is effective in the long term until ten years for CuT-380A. However, acceptors still do not perceive IUD as the primary contraception choice because the acceptors do not understand the benefit. The information that is not complete and effective given by the contraception service officer is the main reason for the lack of understanding of IUD. On the other hand, the cultural aspect also influences the use of IUD. Several women do not want to use IUDs because they are ashamed of their husbands and will not use them. ${ }^{17}$ The rumors about IUD failure also create fear and discomfort to use IUD.

Health counseling about contraception is essential to provide more knowledge about how to use contraception and improve the attitude and behavior of the family toward the Family Planning Program. The counseling ideally could improve the knowledge about Family Planning Program and its services. Furthermore, understanding and positive reactions from the society on Family Planning Program are expected to improve the nation's prosperity.

Several studies on the effectiveness of health counseling showed that it could improve society's knowledge, attitude, and behavior on the use of IUD to control the birth rate in Indonesia and other countries. ${ }^{15,16,18-20}$

Serang regency is an area that includes 29 districts. Its population is composed of 742,298 males and 720,296 females. The citizens are generally aware of contraception, and they have been using contraception with various methods and choices. It shows that most citizens are openminded and willing to support the government's program in controlling the birth rate. However, according to the Women Empowerment and Family Planning Agency of Serang regency data, most citizens prefer to use short-term contraception such as pills and injections. The data also reported that in Bojong Menteng village, Tunjung Teja district, only 15 of 562 married couples use IUD. ${ }^{21}$

The previous study found that the low rate of IUD usage in Bojong Menteng village is caused by the lack of information that allows negative rumors about IUD to spread widely. Furthermore, counseling provided by the counselor is not exciting and persuasive enough, although IUD induction service is provided in health centers. ${ }^{21}$ In addition, information about IUD is not entirely written in the leaflet created by Women Empowerment and Family Planning Agency.

This health campaign is conducted through counseling. Counseling aims to change the behavior, attitude, and knowledge of the communicants so that they are willing to 
apply the innovation provided to improve the life quality of family and society. Thus, every counselor would understand the factors related to the communicant's motivation in joining the counseling.

Counseling as a learning process is one of the ways to persuade society to be more active during the learning process. The learning process itself is a process of delivering responses toward every stimulation received during the learning process. Thus, every counselor needs to understand the stimulus-response theory that someone will respond to the stimulus received. The clarity in communication is determined by four elements: source, message, channel, and communicant. ${ }^{22-25}$

Human receives knowledge through experiences. Knowledge is the result of a human's senses, or someone's understanding of an object through senses (eyes, nose, ears, and others). The process of gaining knowledge is influenced by the intensity of attention and perception toward a specific object. Most of the knowledge is gained through ears and eyes. Every individual's knowledge has a different intensity or level. The level is generally divided into six levels of knowledge: (1) know, (2) comprehension, (3) application, (5) synthesis, and (6) evaluation. ${ }^{26}$

Attitude is the response toward stimulus or particular objects involving argumentation and emotions (happy-not happy, agreedisagree). Attitude is a syndrome or a collection of indications in responding to a stimulus or object. Thus, attitude involves thinking, feeling, attention, and other psychological indications. ${ }^{27,28}$ Knowledge, thinking, belief, and emotion are essential in deciding attitude. The level of attitude is varies depending on the intensity, such as (1) receiving, (2) responding, (3) valuing, and (4) responsible. ${ }^{26}$ Behavior is the activity of an individual that includes walking, talking, crying, laughing, working, studying, writing, reading, etc. Based on the form of the response toward the stimulus, the behavior could be divided into two: (1) covert behavior and (2) overt behavior. ${ }^{26}$

Knowledge is the result of a learning process where an individual sensing a specific objectsensing through human senses such as sight, hearing, smell, taste, and touch. Most of the human's knowledge is gained through sight and hearing. ${ }^{26}$ Knowledge of cognition is an essential domain of behavior forming (overt behaviour).

According to the constructivist approach, knowledge is dissimilar to a studied truth- however, cognitive construction of an individual towards an object, experience, and environment. Therefore, knowledge is not an available material that people can utilize anytime they need it. Instead, it is a systematic forming process that will experience changes along with new understandings. Furthermore, counseling through the leaflet and KIE kit as communication, information, and education media is essential in deciding IUD as a contraception method. It provides reference/technical information on IUD and breaks the stereotype that raises concerns about IUD.

Two factors influence knowledge: (1) education and (2) mass media/information. ${ }^{29,30}$ In the experiment group, respondents received an interesting and informative leaflet and a presentation on using IUD through the KIE kit. The respondents of the experiment group showed enthusiasm when the KIE kit was presented and explained. The enthusiasm can also be perceived through the average increase in statistic calculation.

According to S-O-R theory on counseling, stimulus in the form of a message about IUD has been tested. Response or reaction toward the message will result in an agreement or vice versa. Thus, the theory assumed that certain verbal words, signs, non-verbal, and symbols would stimulate others to respond in specific ways.

The experiment group in this study showed that information media through the leaflet and KIE kit with direct explanation positively impact the change in knowledge and attitude, shown by the increase in average knowledge and attitude after the experiment.

Meanwhile, the respondents of the control group were counseled only through leaflets as the media. The leaflet received is the same as the one that the experimental group also received. It has understandable information with an interesting design. Although the counseling was conducted by only distributing leaflets, the counseling has a positive impact on the control group and the experiment group. It was shown by the increase in average knowledge and attitude after the experiment on the control group. The finding indicates that the leaflet could provide enough information about IUD to the respondents.

The findings are in line with the research conducted by Antini and Trisnawati ${ }^{31}$ on choosing contraception, Zuhriyah et $\mathrm{al}^{32}$ on Family Planning village, Farrar et $a .^{20}$ on the 
importance of contraception, Yoo et al. ${ }^{33}$ on health communication, and health campaign. ${ }^{34}$

\section{Conclusion}

The counseling through leaflets, information education counseling kit, and direct explanation have positive responses.

\section{Conflict of Interest}

There was not a conflict of interest in this article.

\section{Acknowledgments}

The researcher would like to thank the Chancellor of Universitas Mercu Buana Jakarta and the Chief of Postgraduate Universitas Mercu Buana, who have provided opportunities.

\section{References}

1. National Population and Family Planning Board (BKKBN), Statistics Indonesia (BPS), Ministry of Health (Kemenkes), ICF. Indonesia demographic and health survey 2017. Jakarta: BKKBN,BPS, Kemenkes, ICF; 2018.

2. Sulistyawati A. Pelayanan keluarga berencana. Jakarta: Salemba Medika; 2014.

3. Effendy OU. Ilmu, teori dan filsafat komunikasi. Bandung: Citra Aditya Bakti; 2008.

4. Zulkarnain. Psikologi dan komunikasi massa. Tasâmuh. 2015;13(1):45-58.

5. Wicaksono RR, Aniriani GW, Nasihah M. Penggunaan stimulus response theory dalam sosialisasi budaya kesehatan dan keselamatan kerja di perusahaan. J EnviScience. 2017;1(1):31-7.

6. Mulyana A, Hamid F, Mansur S, Susilawati. Kepemimpinan efektif melalui kompetensi komunikasi di Media Nusantara Citra Group. J Kaji Komun. 2019;7(2):184-97.

7. Rogers EM. Evolution: diffusion of innovations. In: Wright JD, editor. International encyclopedia of the social \& behavioral sciences. $2^{\text {nd }}$ Edition. Oxford: Elsevier Inc.; 2015. p. 378-81.

8. Thomas RK. Health communication. New York: Springer Science+Business Media, Inc.; 2006.

9. Rice RE, Atkin CK. Theory and principles of public communication. In: Rice RE, Atkin CK, editors. Campaigns public communication. Thousand Oaks: SAGE Publications, Inc.; 2013. p. 3-20.

10. Abroms LC, Lefebvre RC. Obama's wired campaign: lessons for public health communication. $\mathrm{J}$ Health Commun. 2009;14(5):415-23.

11. Snyder LB. Health communication campaigns and their impact on behavior. $\mathrm{J}$ Nutr Educ Behav. 2007;39(2 Suppl):S32-40.

12. Grier S, Bryant CA. Social marketing in public health. Annu Rev Public Health. 2005;26:319-39.

13. Sugiyono. Metode penelitian kuantitatif, kualitatif, dan R\&D. $2^{\text {nd }}$ Edition. Bandung: Alfabeta; 2019.

14. Destyowati M. Hubungan tingkat pengetahuan ibu tentang kontrasepsi IUD dengan minat pemakaian kontrasepsi IUD di Desa Harjobinangun Kecamatan Grabak Kabupaten Purworejo tahun 2011. JKK. 2012;3(2):30-9.

15. Dehlendorf C, Tharayil M, Anderson N, Gbenedio K, Wittman A, Steinauer J. Counseling about IUDs: a mixed-methods analysis. Perspect Sex Reprod Health. 2014;46(3):133-40.

16. Blumenthal PD, Voedisch A, GemzellDanielsson K. Strategies to prevent unintended pregnancy: increasing use of long-acting reversible contraception. Hum Reprod Update. 2011;17(1):121-37.

17. Nasution SL. The effect of knowledge about adolescent reproductive health on pre marital sexual behaviour in Indonesia. Widyariset. 2012;15(1):75-83.

18. Won SH, Hooton A, Sweeney T. Reactions to the IUD among young women: an online survey testing marketing materials for an IUD education campaign. Contraception. 2012;86(2):186.

19. Wu J, DiCicco-Bloom B, Greenberg S, Sahulhameed F. Breaking the cycle of adolescent pregnancy: can mothers influence their daughters' contraceptive behavior? Contraception. 2012;86(2):186.

20. Farrar SC, Yenari J, Gherman RB. Emergency contraception: a "fire extinguisher" for unintended pregnancies. Prim Care Update Ob Gyns. 2003;10(6):284-7.

21. Badan Pusat Statistik Kabupaten Serang. Statistik Daerah Kecamatan Baros 2015. 
Serang: Badan Pusat Statistik Kabupaten Serang; 2015 [cited 2019 October 15]. Available from: https://serangkab. bps.go.id/publication/2015/11/o2/ adeof 2 f 372 bo 1 abaebaaa 5 f $4 /$ statistikdaerah-kecamatan-baros-2015.html.

22. Ambarwati ER, Khoirunnisa E, Waryana. Health promotion model to increase maternal visit and exclusive breastfeeding in the puerperium period in Sleman, Yogyakarta. JHPB. 2016;1(3):139-49.

23. Merdhika WAR, Mardji, Devi M. Pengaruh penyuluhan ASI eksklusif terhadap pengetahuan ibu tentang ASI eksklusif dan sikap ibu menyusui di Kecamatan Kanigoro Kabupaten Blitar. Teknologi Kejuruan. 2014;37(1):65-72.

24. Wati R. Pengaruh pemberian penyuluhan PHBS tentang mencuci tangan terhadap pengetahuan dan sikap mencuci tangan pada siswa kelas $\mathrm{V}$ di SDN Bulukantil Surakarta [undergraduate thesis]. Surakarta: Universitas Sebelas Maret; 2011 [cited 2019 October 15]. Available from: https://eprints. uns.ac.id/6069/1/197231711201109051.pdf.

25. Benita NR, Dewantiningrum J, Maharani N. Pengaruh penyuluhan terhadap tingkat pengetahuan kesehatan reproduksi pada remaja siswa SMP Kristen Gergaji [undergraduate thesis]. Semarang: Universitas Diponegoro; 2012 [cited 2019 October 15]. Available from: http://eprints. undip.ac.id/37650/1/Nydia_Rena_Benita_ G2A008137_Lap._KTI.pdf.

26. Notoatmodjo S. Promosi kesehatan dan perilaku. Jakarta: Rineka Cipta; 2007.

27. Nuzula F. Psikologi dan komunikasi. ElHikam. 2015;8(2)403-20.

28. Mulyana D. Ilmu komunikasi: suatu pengantar. 21st Printing. Bandung: Remaja Rosdakarya; 2017.

29. Permata SP. Pengetahuan dan sikap remaja terhadap kesehatan reproduksi, kehamilan dan keluarga berencana. J Penelitian UNIB. 2003;9(2):109-14.

30. Suwarto. Dimensi pengetahuan dan dimensi proses kognitif dalam pendidikan. Widyatama. 2010;19(1):76-91.

31. Antini A, Trisnawati I. Hubungan pengetahuan, sikap dan budaya akseptor $\mathrm{KB}$ terhadap pemilihan metode AKDR di wilayah kerja Puskesmas Anggadita Kabupaten Karawang. J Kebidanan. 2016;5(1):11-7.

32. Zuhriyah A, Indarjo S, Raharjo BB. Kampung keluarga berencana dalam peningkatan efektivitas program keluarga berencana. HIGEIA. 2017;1(4):1-12.

33. Yoo SW, Kim J, Lee Y. The effect of health beliefs, media perceptions, and communicative behaviors on health behavioral intention: an integrated health campaign model on social media. Health Commun. 2018;33(1):32-40.

34. Namkoong K, Nah S, Record RA, Van Stee SK. Communication, reasoning, and planned behaviors: unveiling the effect of interactive communication in an anti-smoking social media campaign. Health Commun. 2017;32(1):41-50. 